\title{
Spontaneous extensive pneumocephalous as a rare manifestation of Escherichia coli suppurative meningitis in Diabetic ketoacidosis
}

\author{
Abhishek Dhir, Swati Dahiya, Nidhi Bhardwaj, Monica Gupta
}

Department of General Medicine, Government Medical College and Hospital, Chandigarh, India

\section{Correspondence to} Professor Monica Gupta; monicamanish2001@gmail.com

Accepted 19 January 2020

\section{DESCRIPTION}

Pneumocephalous is characterised by presence of air or gas in the cranial cavity and the majority of cases occurs secondary to a mechanical trauma to skull or neurosurgical intervention. Bacterial meningitis due to Escherichia coli is an extremely uncommon cause of extensive pneumocephalous in a middle aged adult. The pathophysiological mechanism, aetiological agents and radiological imaging study of this unusual entity are discussed.

A 36-year-old woman presented with high grade fever, vomiting, pain abdomen and altered sensorium for 1 week. There was no history of any recent head trauma or neurosurgical procedure or sinus surgery. On evaluation, patient was in altered sensorium with Glasgow Coma Scale of E4V4M5 and nuchal rigidity was present. Laboratory investigations revealed elevated total leucocyte count of $25 \times 10^{9} / \mathrm{L}$, venous plasma glucose of $534 \mathrm{mg} /$ $\mathrm{dL}$, arterial blood gas suggestive of severe high anion gap metabolic acidosis and positive serum and urinary ketones. Serum electrolytes, renal and hepatic profile and chest radiograph were unremarkable.

CT head showed multiple specks of air in subarachnoid spaces of bilateral cerebral hemispheres and bilateral lateral ventricles suggestive of pneumocephalous (figure 1). Cerebrospinal fluid (CSF) analysis showed frank pus with thick coagulum (figure 2), therefore leucocyte count and biochemical estimations were not possible. CSF cytology showed 100\% neutrophils and adenosine deaminase levels were 18. CSF gram staining showed gram negative bacilli, confirmed on culture to be E. coli. Acid fast stain and BACTEC for tuberculosis was negative in CSF. Patient was treated

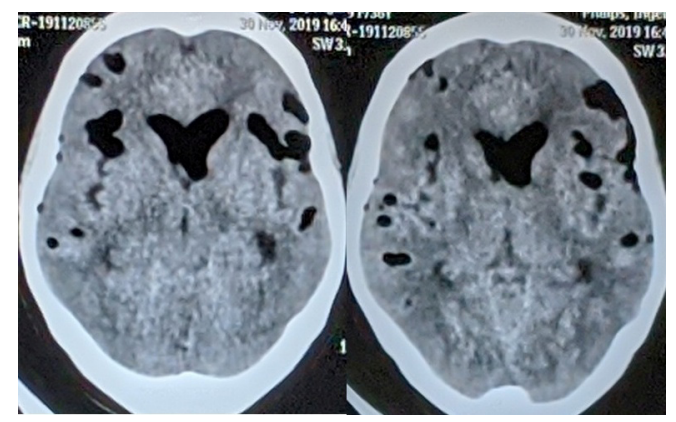

Figure 1 Axial non-contrast CT images of head showing presence of multiple foci of air in the extraaxial cerebrospinal fluid spaces in the bilateral cerebral hemispheres and in the bilateral lateral ventricle.

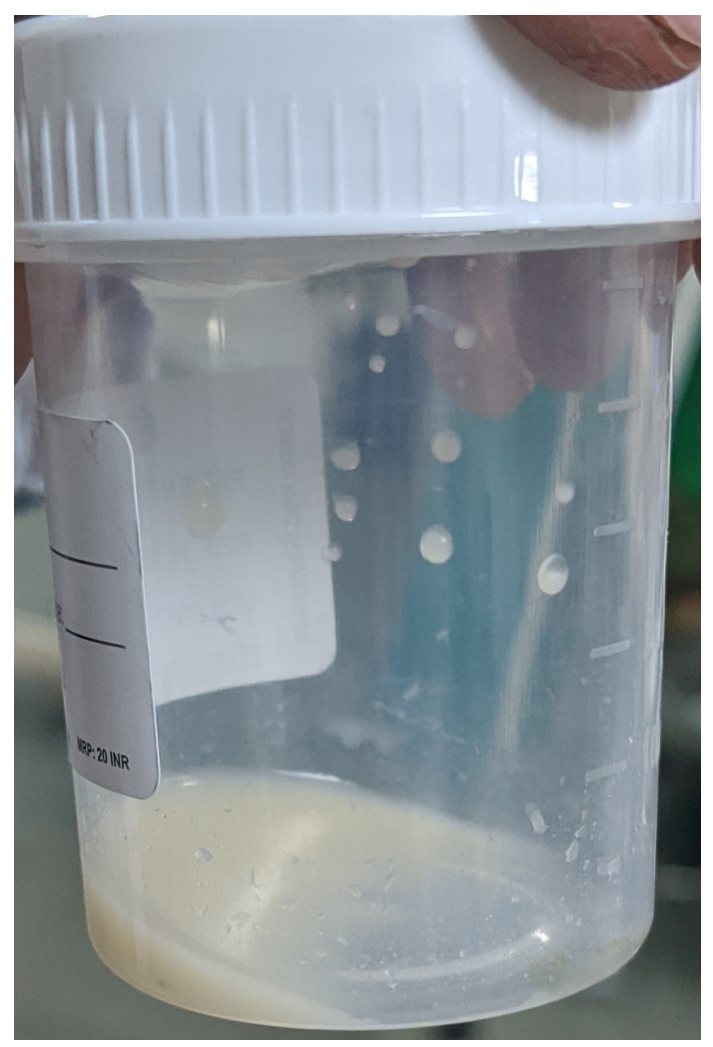

Figure 2 Cerebrospinal fluid suggestive of thick pus.

with meropenem, amikacin and vancomycin, insulin infusion, intravenous fluids and ventilatory support. However she succumbed to the illness on day 3 due to refractory septic shock.

Intracranial air may be attributable to a breach in integrity of the cranial bone or dura, and may result from mechanical trauma or barotrauma, neurosurgical instrumentation or sinus surgery, air embolism or postradiation necrosis of skull appendages and brain abscess or infections due to gas forming organisms. ${ }^{1}$ Intracranial infections produce gas by putrefaction secondary to autolysis of intracellular proteins and glucose decomposition, often in presence of tissue ischaemia. Markham reviewed 295 cases and demonstrated the aetiology of pneumocephalous as trauma in (73.9\%), neoplasm (12.9\%), infections $(8.8 \%)$ and neurosurgical intervention in $3.7 \%$ cases. ${ }^{2}$ Supportive organisms responsible for pneumocephalous comprise species of Esherichia, Klebsiella, Peptostreptococcus, Bacteroides, Fusobacterium, Clostridium, Streptococcus and mixed facultative and anaerobic species. ${ }^{3}$ 


\section{Patient's perspective}

We were not aware of the deranged plasma sugars and the fact that meningitis with air inside the brain can affect my wife's condition to such an extent was devastating for me and my family.

\section{Learning points}

- Spontaneous pneumocephalous may occur as a rare life threatening complication of acute suppurative meningitis in diabetic ketoacidosis.

- Diagnosis of pneumocephalous is often straightforward on CT head, as it is highly sensitive in detecting air in the intracranial compartment. Early suspicion and appropriate antibiotic therapy may save the patient from neurological deterioration.

Clinically, it is important to differentiate simple from tension pneumocephalous which is air collection due to a ball-valve mechanism allowing air to enter the skull but prevents it from escaping, thus creating a pressure differential. ${ }^{4}$ CT is a highly accurate diagnostic tool and air has a Hounsfield coefficient of -1000 , which enables a sensitivity of as little as $0.5 \mathrm{~mL}$ of air in both extra-axial or intra-axial intracranial compartment. ${ }^{5}$ Air over the frontal convexities may appear as 'Mount Fuji sign', and multiple small air bubbles in several cisterns may show "air bubble sign'.5 On MRI the diagnosis may be more difficult as there is no 'objective' density measurement.

Response to treatment depends on the age, clinical status, the extent and progression of the intracranial air, and the underlying aetiology. ${ }^{2}$ Most cases of spontaneous pneumocephalous resolve with urgent antibiotics, supplemental $\mathrm{O}_{2}$ and close monitoring. In fact, there have been cases in literature where children and adult patients with meningitis associated spontaneous pneumocephalous have remarkably responded to prompt early antibiotic therapy, with complete radiological resolution of entrapped gas on a follow-up imaging 2 weeks later. ${ }^{16-10}$

Contributors All the authors have provided substantial contributions in the clinical management of the case and literature review on the topic in question. AD and SD have drafted the manuscript and NB and MG have revised it critically for important intellectual content. All the authors have read the final version and approved it. All the authors agree to be accountable for all aspects of the work in ensuring that questions related to the accuracy or integrity of any part of the work are appropriately investigated and resolved.

Funding The authors have not declared a specific grant for this research from any funding agency in the public, commercial or not-for-profit sectors.

Competing interests None declared.

Patient consent for publication Next of kin consent obtained.

Provenance and peer review Not commissioned; externally peer reviewed.

\section{ORCID iD}

Monica Gupta http://orcid.org/0000-0002-3992-1013

\section{REFERENCES}

1 Kim HS, Kim SW, Kim SH. Spontaneous pneumocephalus caused by pneumococcal meningitis. J Korean Neurosurg Soc 2013;53:249-51.

2 Markham JW. The clinical features of pneumocephalus based upon a survey of 284 cases with report of 11 additional cases. Acta Neurochir 1967;16:1-78.

3 Maliwan N. "Spontaneous" pneumocephalus associated with mixed aerobicanaerobic bacterial meningitis. J Infect Dis 1985;152:847-8.

4 Schirmer CM, Heilman CB, Bhardwaj A. Pneumocephalus: case illustrations and review. Neurocrit Care 2010;13:152-8.

5 Finelli PF, Bergen R. Spontaneous pneumocephalus with meningitis: CT demonstration. J Comput Assist Tomogr 1991;15:525-6.

6 Jayaram S, Jadhav S, Rathod D, et al. Meningitis: an unusual cause of pneumocephalus. J Assoc Physicians India 2004;52:67-8.

7 Kumari A, Agrawal SC. Pneumocephalus consequent to staphylococcal pneumonia and meningitis. J Pediatr Neurosci 2011;6:84-6.

8 Ramakrishnan S, Krishnan P, Chandra PS, et al. Pneumocephalus in mixed aerobic and anaerobic (Bacteroides fragilis) meningitis. Indian J Pathol Microbiol 2014;57:160-1.

9 Pantangi P, Cherian SV. Pneumocephalus; a rare presentation of streptococcal meningitis. Intern Med 2011;50:2249-50.

10 Rota E, Sacchini D, Paolillo F, et al. Pneumocephalus as uncommon presentation of pneumococcal meningitis. Neurol India 2013;61:314-5.

Copyright 2020 BMJ Publishing Group. All rights reserved. For permission to reuse any of this content visit

https://www.bmj.com/company/products-services/rights-and-licensing/permissions/

BMJ Case Report Fellows may re-use this article for personal use and teaching without any further permission.

Become a Fellow of BMJ Case Reports today and you can:

- Submit as many cases as you like

- Enjoy fast sympathetic peer review and rapid publication of accepted articles

- Access all the published articles

Re-use any of the published material for personal use and teaching without further permission

Customer Service

If you have any further queries about your subscription, please contact our customer services team on +44 (0) 2071111105 or via email at support@bmj.com.

Visit casereports.bmj.com for more articles like this and to become a Fellow 